"Ceria"

Jurnal Program Studi Pendidikan Anak Usia Dini

ISSN 2301-9905

Volume 13, No 2 Januari 2021

Fakultas Keguruan dan Ilmu Pendidikan - Universitas Muhammadiyah Tangerang

\title{
Peran Orangtua Dalam Pembiasaan Mencuci Tangan Pada Anak di Masa Pandemi Covid-19 di Kecamatan Kalideres Jakarta Barat
}

\author{
${ }^{1}$ Evy Fitria ${ }^{2}$ Mukhlisoh \\ 1,2 Program Studi Pendidikan Guru Pendidikan Anak Usia Dini ; Fakultas Keguruan Dan Ilmu \\ Pendidikan ; Universitas Muhammadiyah Tangerang \\ email:ㄹvifitria7@gmail.com, ${ }^{2}$ iismukhlisoh94@gmail.com
}

\begin{abstract}
Abstrak
Penelitian ini untuk bertujuan mengetahui peran orangtua dalam pembiasaan mencuci tangan pada anak di Masa Pandemi Covid-19. Informan dalam penelitian ini ialah Orangtua dan Anak yang berjumlah 5 Orangtua dan 5 Anak di Daerah Kecamatan Kalideres Jakarta Barat dengan 5 Kelurahan Semanan, Kalideres, Kamal, Pegadungan, Tegal Alur pada tahun 2020. Fokus Penelitian antara lain; 1) Pembiasaan Mencuci Tangan, 2) Kendala orangtua mengajarkan mencuci tangan, dan 3) penyebab yang diharuskan mencuci tangan. Penelitian ini merupakan jenis penelitian Kualitatif Studi Kasus dengan teknik Pengumpulan Data di ambiil dengan cara Wawancara, Observasi, dan Dokumentasi. Hasil penelitian ini adalah 1) Peran orangtua sangat penting dalam hal mengingatkan kepada anaknya kapan waktu mencuci tangan, memberikan contoh kepada anak tentang cara-cara mencuci tangan dengan baik dan benar agar anak terbiasa dalam mencuci tangan, 2) Kendala yang dihadapi orang tua saat membiasakan anak mencuci tangan saat akan melakukan kegiatan, pulang dari berpergian ialah anak masih menangis dan berterik saat diingatkan untuk mencuci tangan., 3) Penyebab yang di haruskan mencuci tangan yaitu orangtua selalu mengingatkan kepada anaknya waktu anak harus mencuci tangan.
\end{abstract}

Kata kunci : Mencuci tangan, Orang Tua, Pandemi

\section{Pengantar}

Pengalaman dan pendidikan yang tepat sejak anak usia dini akan mempengaruhi kehidupan dewasanya kelak. Pendidikan anak usia dini merupakan pendidikan yang menentukan terbentuknya perilaku dan kepribadian anak. Mulyasa (2012:16). Pendidikan anak 


\section{Jurnal Program Studi Pendidikan Anak Usia Dini}

"Ceria"

usia dini merupakan peletak dasar pertama dan utama dalam pengembangan pribadi anak baik berkaitan dengan karakter, kemampuan fisik, kognitif, bahasa, seni sosial emosional, spiritual, disiplin diri, maupun kemandirian. "Anak usia dini adalah individu yang sedang mengalami proses pertumbuhan dan perkembangan yang sangat pesat, bahkan dikatakan sebagai lompatan perkembangan. Anak usia dini memiliki rentang usia yang sangat berharga dibanding usia-usia selanjutnya karena perkembangan kecerdasanya sangat luar biasa. Usia tersebut merupakan fase perkembangan yang unik, dan berada pada masa proses perubahan berupa pertumbuhan, perkembangan, pematangan dan penyempurnaan baik aspek rohani maupun jasmaninya (Permatasari, 2016). Keunikan anak usia dini disebabkan oleh pengalaman yang diterima anak melalui proses belajar melalui lingkungan sekitar.

Pendidikan pertama anak adalah keluarga (orangtua). Keluarga (orangtua) berperan sebagai pendidik, pembimbing dan pelindung. Orangtua memegang peranan yang sangat penting dalam membentuk karakter seorang anak Ihsan (2005 :57). Orang tua sejatinya adalah pendidik pertama bagi setiap anaknya. Sejak anak lahir, anak belajar mendengar, meniru dan berkata melalui gerakan dan suara ibunya. Tidak hanya pendidikan, orang tua juga memberikan pengasuhan, melalui sikap, tutur kata dan peraturan dalam rumah. Dengan demikian bentuk pertama dari berkembangnya watak, budi pekerti dan pendidikan terdapat dalam kehidupan kepribadian tiap-tiap manusia (Tambak, Ahmad, \& Helman, 2017)

Menurut Depkes (2003) dalam jurnal (Rikayanti, 2014) cuci tangan harus dilakukan dengan benar sebelum dan sesudah melakukan tindakan perawatan meskipun memakai sarung tangan atau alat pelindung lain untuk menghilangkan atau mengurangi mikroorganisme yang ada ditangan sehingga penyebaran penyakit dapat dikurangi dan lingkungan terjaga dari infeksi. Indikasi cuci tangan harus dilakukan pada saat yang diantisipasi akan terjadi perpindahan kuman melalui tangan, yaitu sebelum melakukan tindakan yang dimungkinkan terjadi pencemaran dan setelah melakukan tindakan yang dimungkinkan terjadi pencemaran. Kebiasaan mencuci tangan dengan menggunakan sabun dan air mengalir, adalah bagian dari perilaku hidup sehat yang merupakan salah satu dari tiga pilar pembangunan bidang 
kesehatan yakni perilaku hidup sehat, penciptaan lingkungan yang sehat serta penyediaan layanan kesehatan yang bermutu dan terjangkau oleh semua lapisan masyarakat. Perilaku hidup sehat yang sederhana seperti mencuci tangan dengan sabun dan air mengalir merupakan salah satu cara untuk meningkatkankesadaranmasyarakat tentang pemeliharaan kesehatan pribadi dan pentingnya berperilaku hidup bersih dan sehat.

Menurut Rahayu (2016) bahwa mencuci tangan merupakan teknik dasar yang paling penting dalam pencegahan dan pengontrolan infeksi Mencuci tangan tidak benar akan berakibat fatal terserang berbagai penyakit seperti: Cacingan, TB, infeksi tangan, mulut, ISPA, diare, hingga penyakit mematikan karena kuman masih menempel pada tangan akan mengakibatkan gangguan kesehatan yang paling rentan terjadi pada anak. Berdasarkan pemaparan diatas dapat disimpulkan bahwa mencuci tangan sering dianggap sebagai hal yang sangat mudah dimasyarakat, padahal mencuci tangan bisa memberi kontribusi pada peningkatan status kesehatan masyarakat. Berdasarkan hal ini, terlihat bahwa anak-anak usia sekolah mempunyai kebiasaan kurang memperhatikan perlunya mencuci tangan dalam kehidupan sehari-hari. Mereka biasanya langsung makan, makanan yang mereka beli disekitar sekolah tanpa mencuci tangan terlebih dahulu, padahal sebelumnya mereka bermain.

Terkait dengan Covid-19 ini orangtua harus lebih memperhatikan anaknya dalam hal membiasakan mencuci tangan dengan baik dan benar agar terhindari dari viru Covid-19. Menurut Irene Aprilya Meok Terkait dengan Covid-19, Penyebaran virus corona menjadi perhatian banyak orang, termasuk di Indonesia. Ketika dua WNI positif terinfeksi virus corona, masyarakat berbondong-bondong untuk membeli masker agar dapat melindungi diri. Selain itu, menyiapkan hand sanitizer dan tisu basah. Menurut WHO langkah perlindungan dasar terhadap virus corona. Langkah pertama yang disarankan bukan menggunakan masker, tetapi mencuci tangan sesering mungkin. Langkah ini disarankan karena mencuci tangan secara teratur dan menyeluruh akan membunuh virus yang mungkin ada ditangan. Cuci tangan merupakan langkah mudah dan aman untuk melindungi diri dari virus corona COVID-19 (Meok, 2020). 


\section{Metode}

Penelitian kualitatif Furchan (1992) adalah prosedur penelitian yang menghasilkan data deskriptif beberapa kata tertulis/lisan dari orang-orang atau perilaku yang diamati, Bogdan dan Tailor sebagaimana dikutip dari Moleong mendefinisikannya "sebagai prosedur penelitian yang menghasilkan data deskriptif berupa kata-kata tertulis atau lisan dari orang-orang atau perilaku yang dapat diamati" (Junaidi, 2019). Penelitian ini menggunakan metode penelitian kualitatif yaitu mendeskripsikan kajian "peran orangtua dalam pembiasaan mencuci tangan pada anak di masa pandemi Covid-19 di Kecamatan Kalideres Jakarta Barat" dalam penelitian kualitatif dapat beberapa pendekatan yang dilakukan diantaranya: pendekatan Biografi, pendekatan Fenomenologi, pendekatan Grounded Theory, pendekatan Etnografi, pendekatan Studi-Kasus. Dan peneliti menggunakan Pendekatan studi kasus.

Menurut Stake 1995 dalam Manab (2008) studi kasus adalah eksploras dari sistern terikat atau sebuah kasus dari waktu ke waktu melalui pengumpulan data mendalam dan mendetail yang melibatkan sumber-sumber informasi yang banyak dengan konteks yang kaya. Sistem terikat ini terikat oleh waktu dan tempat, dan hal itu adalah kasus yang sedang ditelitiprogram, kejadian, aktivitas, atau orang-orang Informasi dari banyak sumber termasuk pengamatan, wawancara, materi audio-visual, dan dokumen-dokumen serta laporan-laporan. Wawancara, studi dokumen dan observasi aktivitas anak dan orang tua dilakukan peneliti guna memperoleh data secara menyeluruh dan mendalam, terkait bagaimana pembiasaan

mencuci tangan anak, kendala-kendala yang dihadapi orang tua dan alasan anak-anak perlu mencuci tangannya.

\section{Hasil dan Pembahasan}

Penelitian dilakukan di Kecamatan Kalideres Jakarta Barat dari beberapa kelurahan yaitu : Semanan, Kalideres, Kamal, Pegadungan, Tegal Alur. Penelitian ini dilakukan dari bulan september sampai oktober. Teknik pengambilan data melalui wawancara online, observasi; 
Jurnal Program Studi Pendidikan Anak Usia Dini

"Ceria"

1. Peran orangtua selalu mengingatkan kepada anak, kapan waktu untuk mencuci tangan, memberi contoh kapada anak tentang cuci tangan dan bagaimana cara-cara mencuci tangan dengan baik dan benar agar anak terbiasa dalam mencuci tangan. Orangtua megajarkan kepada anaknya cara mencuci tangan secara perlahan-lahan dan sesuai dengan langkah-langkah mencuci tangan secara benar. Orang tua bertindak sebagai model atau memberikan contoh untuk berperilaku hidup bersih.

2. Orangtua selalu mengingatkan kepada anaknya dalam mencuci tangan, orangtua ketiak anakanya tidak mencuci tangan menggunakan sabun dan air mengalir, tangan anak ada kuman dan mudah terkena penyakit. Orangtua mengajarakan anaknya tentang tujuan mencuci tangan itu apa dan akibatnya jika anak tidak mencuci tangan maka akan bau dan banyak kuman yang masuk kedalam tubuh kita, sehingga badan kita akan merasa sakit karena diserang oleh kuman, virus dan bakteri. Para orang tua, selalu memberikan instruksi kepada anak untuk selalu mencuci tangan, namun tidak disertai dengan memberikan contoh atau perilaku hidup bersih yang dilakukan didalam atau luar rumah.

Peran orang tua selalu mengajarkan kepada anaknya cara-cara mencuci tangan dengan baik dan benar agar terhindar dari kuman, orangtua selalu mengingtakan kepada anaknya kapan waktu mencuci tangan dan kegiatan apa saja yang harus mencuci tangan agar anak terbiasa dalam mencuci tangan. Anak selalu melakukan mencuci tangan sebelum dan sesudah kegiatan dan orangtua juga selalu mengingatkan kepada anaknya ketika anak suka lupa, malas, menangis karena tidak mau mencuci tangan. Anak selalu mengerjakan mencuci tangan sebelum dan sesudah kegiatan contohnya : sebelum makan dan sesudah makan, dll

\section{Kesimpulan}

Berdasarkan hasil uraian maka dapat disimpulkan orang tua memiliki peranan penting dalam pembiasaan mencuci tangan di masa pandemi. orang tua tidak hanya berperan sebagai pengingat tetapi juga terlibat langsung dengan cara memberikan contoh dan selalu berupaya 
untuk mengingatkan anak untuk selalu mencuci tangan secara lisan. Kendala yang dihadapi anak ialah anak masih menangis dan marah saat diingatkan. Selain itu orang tua perlu memajang / menempel langkah-langkah mencuci tangan yang benar di pintu toilet, dengan harapan anak dapat melihat dan mempraktekannya. selain itu juga ajak anak untuk menonton berita terkait pandemi atau membacakan buku cerita pentingnya mencuci tangan terakhir adalah orang tua perlu menanamkan displin bagi anak, berikan pujian jika anak mampu melakukan cuci tangan dengan benar dan nyatakan secara ekspresif perasaan orang tu jika anak melanggar perjanjian untuk tidak mencuci tangan

\section{Daftar Pustaka}

Junaidi, H. (2019). kualitas metode penelitian program strata 1dalam pengarusutamaan gender. Jurnal Kajian Gender Dan Anak, 14, 107-127.

Manab, A. (2008). penelitian pendidikan pendekatan kualitatif.

Meok, I. aprilya. (2020). Cara Cuci Tangan yang Benar untuk Cegah Virus Corona COVID-19.

4 maret, 1-13. https://tirto.id/cara-cuci-tangan-yang-benar-untuk-cegah-virus-coronacovid-19-eCPj

Rikayanti, K. (2014). Hubungan Tingkat Pengetahuan Dengan Perilaku Mencuci Tangan Petugas Kesehatan Di Rumah Sakit Umum Daerah Badung Tahun 2013. Community Health, 2(1).

Sugiono. (2018). METODE PENELITIAN KUANTITATIF, KUALITATIF DAN R\&d. In ALFABETA (Vol. 2).

Permatasari, E. D. ayu. (2016). MENINGKATKAN RASA PERCAYA DIRI PADA ANAK USIA 4-5 TAHUN MELALUI GERAK DAN LAGU. UNIVERSITAS SLAMET RIYADI, 1(18), 71-78. http://ejurnal.unisri.ac.id/index.php/jpaud/article/view/1476

Tambak, S., Ahmad, M. Y., \& Helman. (2017). Peran Orang Tua Dalam Mengembangkan Kecerdasan Emosional Anak di Desa Petonggan Kecamatan Rakit Kulim Kabupaten Indragiri Hulu. Jurnal Al - Hikmah, 14(2) 